\title{
Environmentally Friendly Extraction of Bioactive Compounds from Mentha arvensis Using Deep Eutectic Solvent as Green Extraction Media
}

\author{
Zubera Naseem¹, Muhammad Zahid ${ }^{1 *}$, Muhammad Asif Hanif ${ }^{1}$, Muhammad Shahid ${ }^{2}$ \\ ${ }^{1}$ Department of Chemistry, University of Agriculture, Faisalabad, Pakistan \\ ${ }^{2}$ Department of Biochemistry, University of Agriculture, Faisalabad, Pakistan
}

Received: 9 October 2019

Accepted: 14 November 2019

\begin{abstract}
In the present study, deep eutectic solvent (DES) was prepared by combining choline chloride and glycerol and is used as a green alternative extraction media of detrimental organic solvents. The DES and aqueous methanol were used for the ultrasound-assisted extraction (UAE) of bioactive compounds from Mentha arvensis, which have remarkable medicinal values. The optimization of extraction parameters during phytochemical evaluation was done by response surface methodology. The extraction yield obtained with DES was significantly higher than that achieved using aqueous methanol. The total phenolic contents (TPCs) $117 \mathrm{mg} \mathrm{GAE} / \mathrm{g}$, total flavonoids contents (TFCs), $80 \mathrm{mg}$ QE/g and 2, 2-diphenyl-1- picrylhydrazyl (DPPH) radical inhibition 94\% was obtained using DES. The antimicrobial activities of extracts were evaluated against $S$. aureus, E. coli (bacterial strains), F. solani and $A$. niger (fungal strains) by well diffusion method. The extracts were characterized using LC-MS and showed that chrysin, p-coumaric acid, naringenin, scopoletin, phenylpyruvic acid, pinocembrin, hesperidin, carnosic acid and caffeic acid were the main bioactive components of Mentha arvensis. The DES has shown considerable high extraction yield, which ultimately relates to the higher TPCs, TFCs and DPPH assay compared to aqueous methanol. The DES with extensive hydrogen bonding is of vital importance in the perspective of the environment than traditionally used solvents.
\end{abstract}

Keywords: deep eutectic solvent, Mentha arvensis, ultrasound-assisted extraction, response surface methodology, LC-MS

\section{Introduction}

Volatile organic solvents (VOCs) have a detrimental influence on the environment and human beings. The

*e-mail: rmzahid@uaf.edu.pk

eutectic-based mixtures actually consist of organic compounds having lower melting points in contrast to their individual constituents [1]. The DESs are one of the alternatives of organic solvents for the extraction of bioactive compounds because of unique physicochemical properties. Characteristically, DES is defined as a mixture of hydrogen bond donors (HBD) and an acceptor system with extensive intermolecular 
hydrogen bonding. According to an investigation by Abbott, the delocalization of charges between hydrogen bond donor and halide anion is accountable for the lowering of the melting point [2]. In comparison with traditional organic solvents, DESs are more acceptable at the pharmaceutical level due to non-volatility and low toxicity [3].

In the pharmaceutical sector, medicinal plants are familiar due to a wide range of secondary metabolites that have enormous pharmacological activities [4]. The phenolic compounds of plants have an assortment of biological effects, including antioxidant potential. The antioxidant potential of phenolic compounds is mainly endorsed to their redox properties, which allow them to act as hydrogen bond donors, reducing agents, and singlet oxygen quenchers [5]. Mentha arvensis belongs to the family Lamiaceae and is famous for its therapeutic and medicinal values since prehistoric times. It has been reported in various studies that plant extracts of Mentha have been found to possess bioactive ingredients that showed antioxidant, antifungal and antibacterial activities [6].

The process of optimization in the conventional method is based on the study of one factor at a time, which is time-consuming, and interaction among various parameters cannot be studied. The response surface methodology (RSM) facilitates to assess the linear, quadratic and interactive effects of independent variables on the response variables. Therefore, RSM is supportive to find the linear and interactive effects of several parameters simultaneously. In the present work, choline chloride and glycerol-based DES was used for the extraction of biologically active compounds from Mentha arvensis. The extraction of phytochemicals was carried out using the UAE method, and optimization of the process was studied using RSM. The TPCs, TFCs, antioxidant potential, antibacterial and antifungal activities of plant extracts were also evaluated. The identification of various bioactive compounds was done using LC-MS.

\section{Material and Methods}

\section{Reagents/Materials}

Reagents/Materials include choline chloride (DaeJung, 99\%), glycerol (Dae-Jung, 99.50\%), methanol (PubChem, 99.85\%) Folin-Ciocalteu reagent (SigmaAldrich, 99.99\%), DPPH (Sigma-Aldrich, 99.50\%), ethanol (Riedel-deHaen, 99.80\%), aluminium chloride (Sigma-Aldrich, 99.99\%), $\mathrm{Na}_{2} \mathrm{CO}_{3}$ (Riedel-deHaen, 99\%), $\mathrm{CH}_{3} \mathrm{COOK}$ (Sigma-Aldrich, 99\%), nutrient agar (Himedia, 99\%), potato dextrose agar (Tmmedia, 99\%), and Sabouraud dextrose agar (Applichem, 99\%).

Mentha arvensis L. (pudina) was purchased from a local market and valid identification was conceded from the Department of Botany at the University of Agriculture in Faisalabad, Pakistan. The whole plant material was cleaned with tap water in order to remove the dirt particles, and dried in shade for approximately 30 days. The dried material was ground using a mechanical grinder and sieved to achieve mesh size of $250 \mu \mathrm{m}$. The voucher sample was kept in an airtight container, assigned a number and stored at ambient temperature $\left(25 \pm 5^{\circ} \mathrm{C}\right)$ for further analysis.

\section{Preparation of DES}

The choline chloride and glycerol were dried in a drying oven at $60^{\circ} \mathrm{C}$ for 24 hours before use [7]. These individual components (i.e., choline chloride and glycerol) were weighed with specific mole ratios (1:2) and placed in a bottle with a Teflon-lined stirring bar in water bath below $80^{\circ} \mathrm{C}$ until a colorless, transparent and homogenous liquid was formed.

\section{Extraction of Phytochemicals}

The extraction of bioactive compounds was performed using an ultrasonic bath generating $40 \mathrm{KHz}$ frequency. For this purpose, $2 \mathrm{~g}$ dried plant material was extracted with $20 \mathrm{~mL}$ of DESs and aq. $\mathrm{MeOH}$ separately. The dried plant material along with respective solvent was kept in an ultrasonic bath (2.5 L 250W DSA50-SK2 Digital Ultrasonic Cleaner) at different levels of time (15-60 minutes), temperature $\left(40-70^{\circ} \mathrm{C}\right)$ and biomass-to-solvent ratio $(0.5-2.0 \mathrm{~g} / 10 \mathrm{~mL})$ [8]. The extraction yield is evaluated as:

$$
\text { Extraction yield }=\frac{\text { weight of extracted product }}{\text { weight of plant material }}
$$

\section{Response Surface Methodology}

The parameters like extraction time, temperature and biomass-to-solvent ratio that influence the extraction process of phenolic compounds were evaluated and optimized by Box-Behnken design [9]. The ranges of these independent variables were evaluated with both solvents in preliminary experiments during extraction yield determination. The 17 experiments were conducted randomly to analyze the significance of applied quadratic model against TPC, TFC and DPPH inhibition responses. The coded levels of independent variables used for BBD are given in Table 1.

Table 1. Coded levels of independent variables.

\begin{tabular}{|c|c|c|c|}
\hline \multirow{2}{*}{ Independent variables } & \multicolumn{3}{|c|}{ Factor levels } \\
\cline { 2 - 4 } & -1 & 0 & +1 \\
\hline Time $($ min. $)$ & 30 & 45 & 60 \\
\hline Temperature $\left({ }^{\circ} \mathrm{C}\right)$ & 50 & 60 & 70 \\
\hline Biomass $(\mathrm{g} / 10 \mathrm{~mL})$ & 1 & 1.5 & 2 \\
\hline
\end{tabular}


The experimental data of dependent variables was fitted in a $2^{\text {nd }}$-order polynomial Equation (1):

$$
Y=\beta_{0}+\sum_{i=1}^{3} \beta_{0} X_{i}+\sum_{i=1}^{3} \beta_{i i} X_{i}^{2} \sum_{i=1}^{2} \sum_{j=i+1}^{3} \beta_{i j} X_{i} X_{j}
$$

$\mathrm{Y}=$ Predicted response

$\beta_{\mathrm{o}}=$ Coefficient for intercept

$\beta_{\mathrm{i}}=$ Linear coefficient

$\beta_{\mathrm{ii}}=$ Quadratic coefficient

$\beta_{\mathrm{ij}}=$ Coefficient for interaction terms

Analysis of variance (ANOVA) was applied to examine the significance of statistical terms in the regression equation [10]. The statistically nonsignificant $(p>0.05)$ terms were not considered in the initial model and the experimental data was justified only by significant $(p<0.05)$ terms. The simultaneous optimization of independent variables was obtained and applied further for the validation of model. The prediction power of the model was justified by comparing the experimental values with the theoretical (predicted) values. All experiments were performed in triplicates and results were expressed as mean \pm standard deviation $(\mathrm{n}=3)$. RSM was performed using Design Expert Software 7.0.

\section{Evaluation of Phytochemicals}

The Folin-Ciocalteau's reagent method with some modification was used for determining the TPC of plant extracts by spectrophotometer [11]. The aluminum chloride colorimetric method with slight modification was used to analyze the TFC of plant extract [12]. The free radical scavenging potential of plant extracts was determined using DPPH radical assay as described previously with some modification [13].

\section{Antimicrobial Activities}

The antimicrobial potential of $M$. arvensis extracts was evaluated against two bacterial strains ( $S$. aureus and $E$. coli) and two fungal strains ( $F$. solani and $A$. niger) using the well diffusion method. Minimum inhibitory concentration (MIC) for each extract was determined by broth micro-dilution method [14].

Sterilized nutrient agar and potato dextrose agar were used for antibacterial and antifungal tests, respectively. $1000 \mu \mathrm{L}$ of bacterial and fungal culture were mixed into respective nutrient medium. Then $50 \mathrm{~mL}$ of media was transferred to each petri plate and permitted to solidify. $100 \mu \mathrm{L}$ of each extract was poured in the wells. Rifampicin and Terbinafin $(100 \mu \mathrm{g} / \mathrm{mL})$ were used as positive controls for antibacterial and antifungal activities. These plates were kept in an incubator at $37^{\circ} \mathrm{C}$ for $24 \mathrm{~h}$ (bacterial activity) and $72 \mathrm{~h}$ (fungal activity). The antibacterial activity was assessed by measuring the zone of inhibition.
Minimum inhibitory concentrations (MICs) of extracts were determined in sterile 96-well microplates. The dilution was done with serially decreasing concentrations with a final volume of $100 \mu \mathrm{L}$ in each micro-plate well. Then $10 \mu \mathrm{L}$ of inoculum was added to each well and plates were incubated at $37^{\circ} \mathrm{C}$ for $24 \mathrm{~h}$ for bacterial strains and $72 \mathrm{~h}$ for fungal strains at $28^{\circ} \mathrm{C}$. After incubation, $10 \mu \mathrm{L}$ of resazurin solution as an indicator was added to each well. Absorbance was recorded at $620 \mathrm{~nm}$ (bacterial) and $520 \mathrm{~nm}$ (fungal), kept in an ELISA reader. The least concentration with no microbial expansion was taken as the MIC value.

\section{Mass Spectrometry}

The phenolics and flavonoids from the optimized extracts were identified by mass spectrometer (LCESI-MS, 8050 Shimadzu, Japan). The C18 column $(2.1 \mathrm{~mm} \times 150 \mathrm{~mm})$ with RI detector RI830 was used for separation. Methanol:water was used as mobile phase. An isocratic elution was executed with a flow rate of $0.2 \mathrm{~mL} / \mathrm{min}$ by subsequent run conditions: (i) $65 \%$ of methanol from 0 to $30 \mathrm{~min}$, (ii) $55 \%$, from 31 to $40 \mathrm{~min}$ (iv) $35 \%$, at $41-60 \mathrm{~min}$ of total run time. $20 \mu \mathrm{L}$ of the sample was injected, and identification of the compounds was carried out under the conditions of negative and positive ion mode with mass range of $50-2000 \mathrm{~m} / \mathrm{z}$, spray electric potential of $4 \mathrm{kV}$, at $325^{\circ} \mathrm{C}$ gas temperature with 40 psi nebulizer pressure.

\section{Results and Discussion}

In this study, DES and aqueous methanol were selected for the extraction of bioactive compounds from $M$. arvensis using UAE. The optimization of time, temperature, and biomass-to-solvent ratio was achieved by RSM. The antioxidant and antimicrobial activities were performed in addition to phytochemical evaluation.

\section{Extraction Yield}

\section{Effect of Time}

The extraction of phytochemicals from $M$. arvensis was carried out at 15, 30, 45 and $60 \mathrm{~min}$. The extraction temperature $\left(60^{\circ} \mathrm{C}\right)$ and biomass-to-solvent ratio (1 $\mathrm{g} / 10 \mathrm{~mL})$ was kept constant during optimization of time. The optimized time with DES and aq. $\mathrm{MeOH}$ was $45 \mathrm{~min}$, with $320 \mathrm{mg} / \mathrm{g}$ and $167 \mathrm{mg} / \mathrm{g}$ of respective yields. The mass was transferred rapidly with accelerated time from 15 to $45 \mathrm{~min}$., and then equilibrium was achieved up to $60 \mathrm{~min}$. with no change in yield with both solvents [15] as shown in Fig. 1a). The cavitation effects increased with the increment of time during sonication, which ultimately enhanced the mass transfer and rate of extraction [16]. 


\section{Effect of Temperature}

The optimization of temperature was carried out at $40,50,60$ and $70^{\circ} \mathrm{C}$, keeping the biomass-tosolvent ratio $(1 \mathrm{~g} / 10 \mathrm{~mL})$ constant. The optimized level of temperature with both solvents was $60^{\circ} \mathrm{C}$, with $315 \mathrm{mg} / \mathrm{g} 170 \mathrm{mg} / \mathrm{g}$ respective yields. The viscosity of DES was also reduced when temperature reached from $50^{\circ} \mathrm{C}$ to $60^{\circ} \mathrm{C}$, which ultimately enhanced the rate of diffusion of plant metabolites in the solvent. When temperature increased up to $70^{\circ} \mathrm{C}$, no appreciable change in yield was observed with both solvents as depicted in Fig. 1b). So the optimum level of $60^{\circ} \mathrm{C}$ temperature was chosen to avoid the degradation of phenolic compounds [17].

\section{Effect of Biomass-to-Solvent Ratio}

The effect of biomass-to-solvent ratio is also an imperative aspect along with time and temperature in UAE. The biomass-to-solvent ratios of $0.5 / 10,1.0 / 10$, $1.5 / 10$ and $2.0 \mathrm{~g} / 10 \mathrm{~mL}$ were chosen while sonication time and temperature were selected according to each solvent as optimized in previous experiments. The DES solvent gave the utmost yield of $311 \mathrm{mg} / \mathrm{g}$ at $1.0 \mathrm{~g} / 10 \mathrm{~mL}$, and yield was reduced at a higher ratio. The yield with aqueous methanol was increased from $0.5 \mathrm{~g} / 10 \mathrm{~mL}$ to $1.5 \mathrm{~g} / 10 \mathrm{~mL}$ and then decreased at $2.0 \mathrm{~g} / 10 \mathrm{~mL}$ as shown in Fig. 1c). The rate of diffusion of solute molecules into solvent is directly influenced by the biomass-to-solvent ratio [18]. Generally, a small biomass-to-solvent ratio can dissolve bioactive ingredients with more efficacy, leading to an enhanced extraction yield. An extensive hydrogen bonding network in DES is responsible for higher extraction yields as compared to aqueous methanol [19].

\section{Response Surface Methodology}

The optimization of extraction time, temperature and biomass-to-solvent ratio (independent variables) was examined comprehensively by BBD experiments for the extraction of bioactive ingredients [20]. The phenolic contents from $M$. arvensis were extracted by DES at three different time intervals $(45,60$ and 75 min.), temperatures $\left(50,60\right.$ and $\left.70^{\circ} \mathrm{C}\right)$ and biomassto-solvent ratios $(0.5 / 10,1.0 / 10$ and $1.5 \mathrm{~g} / 10 \mathrm{~mL})$. The maximum recovery of antioxidant compounds and hence antioxidant activity was observed at $60^{\circ} \mathrm{C}$, with $1 \mathrm{~g} / 10 \mathrm{ml}$ biomass-to-solvent ratio in $60 \mathrm{~min}$. of sonication. The DES gave higher amounts of phenolic contents because this solvent has extensive hydrogen bonding with lower viscosity, which enhances the diffusion process from the matrix. In general, the high temperature decreases the viscosity of solvent, and ultimately the diffusion process of phenolic compounds increased [21]. The close resemblance with the experiment and predicted values was observed during all 17 experiments for all three responses as shown in Table 2.

The three responses for TPCs, TFCs and percentage inhibition (DPPH) were evaluated by applying the $2^{\text {nd }}$ order polynomial equation. The fitness of applied model and statistical significance of linear, quadratic and interaction terms was analyzed by analysis of variance. The p-values $(<0.0001)$ confirmed the significance of each model term [22]. The fitness of model was verified by $\mathrm{R}^{2}$ value, which is the coefficient of correlation between experimental and predicted values of dependent variables. The fairly high $\mathrm{R}^{2}$ values of TPCs, TFCs and DPPH (0.9991, 0.9901, 0.9969) with least standard deviations $(0.89,2.07,1.12)$ described the significance of the regression model. The range of dispersion of data is described by the coefficient of variation $(\mathrm{CV})$ and it is a measure of standard deviation as percentage of mean. The high value of $\mathrm{CV}$ represent the greater variation in mean value, while lesser values of TPCs, TFCs and DPPH $(0.96 \%, 3.22 \%, 1.45 \%)$ gave improved reproducibility of data. The ANOVA is given in Table 3.

The results of DPPH activity show that plant extract is potentially active. This suggests that $M$. arvensis contains high concentrations of bioactive compounds that are responsible for donating hydrogen to a free radical. It is observed that DPPH activity is maximum (94\%) when the TPC (115) and TFC (72) contents are highest in the extract (Table 2, Run 2), and thus a positive correlation has been found between TPCs,
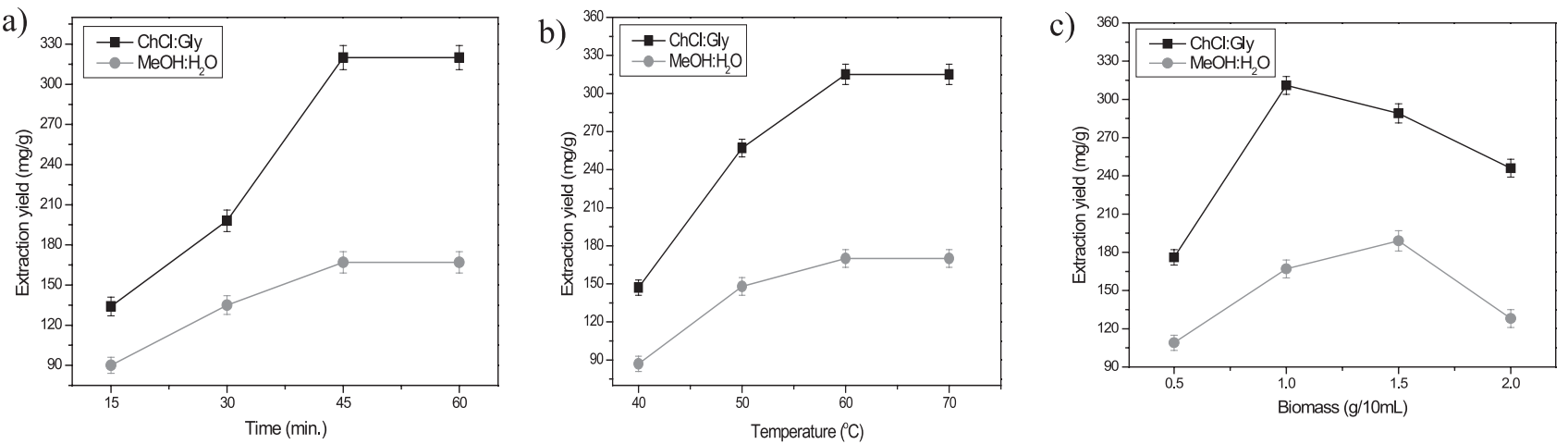

Fig. 1. Effect of time a), temperature b) and biomass-to-solvent ratio c) on extraction yield during UAE. 
Table 2. Experimental and coded values of independent variables and experimental and predicted values of dependent variables using the Box-Bhenken design.

\begin{tabular}{|c|c|c|c|c|c|c|c|c|c|}
\hline \multirow{2}{*}{ Runs } & \multirow{2}{*}{$\begin{array}{c}\mathrm{X} 1 \\
\mathrm{~A}\end{array}$} & \multirow{2}{*}{$\begin{array}{c}\mathrm{X} 2 \\
\mathrm{~B} \\
\end{array}$} & \multirow{2}{*}{$\frac{\mathrm{X} 3}{\mathrm{C}}$} & \multicolumn{2}{|c|}{ Y1 } & \multicolumn{2}{|c|}{$\mathrm{Y} 2$} & \multicolumn{2}{|c|}{ Y3 } \\
\hline & & & & Exp. & Pred. & Exp. & Pred. & Exp. & Pred. \\
\hline 1 & $45(-1)$ & $60(0)$ & $0.5(-1)$ & 69 & 70 & 56 & 58 & 56 & 55 \\
\hline 2 & $60(0)$ & $60(0)$ & $1.0(0)$ & 115 & 116 & 79 & 78 & 94 & 94 \\
\hline 3 & $75(+1)$ & $60(0)$ & $0.5(-1)$ & 71 & 70 & 45 & 43 & 64 & 65 \\
\hline 4 & $45(-1)$ & $70(+1)$ & $1.0(0)$ & 93 & 92 & 66 & 63 & 73 & 74 \\
\hline 5 & $60(0)$ & $70(+1)$ & $0.5(-1)$ & 66 & 66 & 49 & 49 & 59 & 59 \\
\hline 6 & $60(0)$ & $60(0)$ & $1.0(0)$ & 116 & 115 & 80 & 78 & 95 & 94 \\
\hline 7 & $75(+1)$ & $60(0)$ & $0.5(-1)$ & 91 & 90 & 76 & 74 & 75 & 76 \\
\hline 8 & $45(-1)$ & $50(-1)$ & $1.0(0)$ & 90 & 89 & 65 & 63 & 76 & 75 \\
\hline 9 & $75(+1)$ & $50(-1)$ & $1.0(0)$ & 84 & 84 & 48 & 50 & 86 & 84 \\
\hline 10 & $60(0)$ & $50(-1)$ & $1.5(+1)$ & 98 & 97 & 65 & 65 & 81 & 82 \\
\hline 11 & $75(+1)$ & $70(+1)$ & $1.0(0)$ & 78 & 78 & 62 & 64 & 74 & 73 \\
\hline 12 & $60(0)$ & $70(+1)$ & $1.5(+1)$ & 84 & 85 & 63 & 63 & 70 & 69 \\
\hline 13 & $45(-1)$ & $60(0)$ & $1.5(+1)$ & 110 & 109 & 72 & 74 & 78 & 77 \\
\hline 14 & $60(0)$ & $60(0)$ & $1.0(0)$ & 114 & 116 & 76 & 78 & 93 & 94 \\
\hline 15 & $60(0)$ & $50(-1)$ & $0.5(-1)$ & 57 & 56 & 34 & 33 & 58 & 59 \\
\hline 16 & $60(0)$ & $60(0)$ & $1.0(0)$ & 116 & 116 & 78 & 78 & 94 & 94 \\
\hline 17 & $60(0)$ & $60(0)$ & $1.0(0)$ & 117 & 116 & 77 & 78 & 93 & 94 \\
\hline
\end{tabular}

X1 Time (min.), X2 Temperature $\left({ }^{\circ} \mathrm{C}\right)$, X3Biomass (g/10 mL), Y1 TPC (mg GAE/g), Y2 TFC (mg QE/g), Y3 DPPH (\% inhibition)

Table 3. ANOVA statistics of quadratic model designed by Box-Behnken.

\begin{tabular}{|c|c|c|c|c|c|c|c|}
\hline \multirow[b]{2}{*}{ Source } & \multirow[b]{2}{*}{ df } & \multicolumn{2}{|c|}{ Y1 } & \multicolumn{2}{|c|}{ Y2 } & \multicolumn{2}{|c|}{ Y3 } \\
\hline & & F-value & p-value & F-value & p-value & F-value & p-value \\
\hline Model & 9 & 895.10 & $<0.0001$ & 77.97 & $<0.0001$ & 251.57 & $<0.0001$ \\
\hline A-Time & 1 & 223.21 & $<0.0001$ & 22.14 & 0.0022 & 28.74 & 0.0011 \\
\hline B-Temp. & 1 & 8.93 & 0.0203 & 22.95 & 0.0020 & 62.14 & 0.0001 \\
\hline C-Biomass & 1 & 2285.71 & $<0.0001$ & 250.50 & $<0.0001$ & 446.35 & $<0.0001$ \\
\hline $\mathrm{AB}$ & 1 & 28.65 & 0.0011 & 10.67 & 0.0137 & 17.95 & 0.0039 \\
\hline $\mathrm{AC}$ & 1 & 140.00 & $<0.0001$ & 13.17 & 0.0084 & 26.30 & 0.0014 \\
\hline $\mathrm{BC}$ & 1 & 167.94 & $<0.0001$ & 17.93 & 0.0039 & 31.07 & 0.0008 \\
\hline $\mathrm{A}^{2}$ & 1 & 560.37 & $<0.0001$ & 16.38 & 0.0049 & 196.65 & $<0.0001$ \\
\hline $\mathrm{B}^{2}$ & 1 & 1978.71 & $<0.0001$ & 185.09 & $<0.0001$ & 266.04 & $<0.0001$ \\
\hline $\mathrm{C}^{2}$ & 1 & 2162.81 & $<0.0001$ & 132.13 & $<0.0001$ & 1044.86 & $<0.0001$ \\
\hline Residual & 7 & & & & & & \\
\hline Lack of Fit & 3 & 1.39 & 0.3678 & 4.61 & 0.0869 & 5.19 & 0.0729 \\
\hline Pure Error & 4 & & & & & & \\
\hline Cor Total & 16 & & & & & & \\
\hline
\end{tabular}

Y1 (TPC), Y2 (TFC), Y3 (DPPH), Significant $<0.05$, Non-significant $>0.05$ 
TFCs and DPPH activity. The ability of plant extract to scavenge DPPH may also reflect its potential to inhibit the formation of free radicals. This implies that the $M$. arvensis extract may be useful for treating radical related pathological damage [23].

Quadratic model equations in terms of operating parameters (A, B, C) for all three responses:

Quadratic model equation for TPC

$\mathrm{TPC}=-994.82500+6.79750 \mathrm{~A}+25.09125 \mathrm{~B}+301.900 \mathrm{C}$ $-0.015833 \mathrm{AB}-0.7000 \mathrm{AC}-1.1500 \mathrm{BC}$$$
-0.045500 \mathrm{~A}^{2}-0.19237 \mathrm{~B}^{2}-80.4500 \mathrm{C}^{2}
$$

Std. Dev. (0.89), R-Squared (0.9991), Mean (92.26), C.V. $(0.96 \%)$, lack of fit $(0.3678)$

Quadratic model equation for TFC

$$
\mathrm{TFC}=-498.6750+0.0941 \mathrm{~A}+16.3150 \mathrm{~B}
$$

$+138.3150 \mathrm{C}+0.02250 \mathrm{AB}+0.5000 \mathrm{AC}-0.87500 \mathrm{BC}$

$$
-0.018111 \mathrm{~A}^{2}-0.13700 \mathrm{~B}^{2}-46.3000 \mathrm{C}^{2}
$$

Std. Dev. (2.07), R-Squared (0.9901), Mean (64.09), C.V. $(3.22 \%)$, lack of fit $(0.0869)$
Quadratic model equation for DPPH

$$
\begin{gathered}
\mathrm{DPPH}=-544.400+5.56167 \mathrm{~A}+11.95750 \mathrm{~B}+ \\
218.550 \mathrm{C}-0.0158 \mathrm{AB}-0.38333 \mathrm{AC}-0.62500 \mathrm{BC} \\
-0.034056 \mathrm{~A}^{2}-0.089125 \mathrm{~B}^{2}-70.6500 \mathrm{C}^{2}
\end{gathered}
$$

Std. Dev. (1.12), R-Squared (0.9969), Mean (77.59), C.V. $(1.45 \%)$, lack of fit (0.0729)

The interaction between the independent variable and their combined influence on the response values was depicted by 3D response surfaces. The graphical representation of a $3 \mathrm{D}$ response surface is a function of two independent variables against one dependent variable keeping the one independent variable at a fixed level. These surfaces are helpful in understanding the interaction effects of independent variables on the responses [24]. The interaction effects between independent variables on TPC, TFC and DPPH are illustrated in response surfaces generated by the quadratic model, as shown in Fig. 2(a-c). It can be concluded that high and low levels of sonication a)

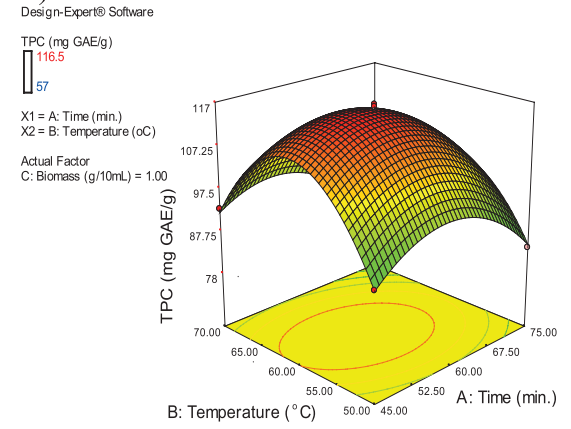

d)

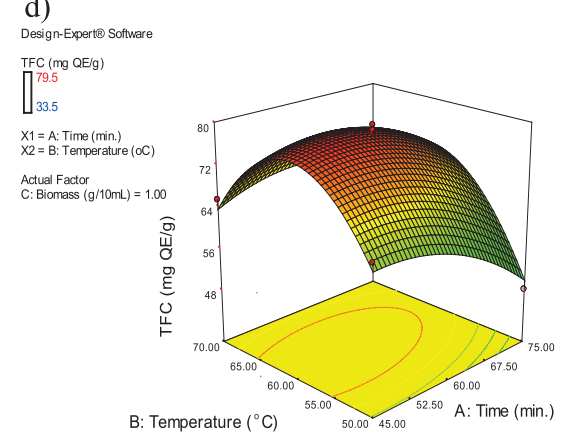

g)

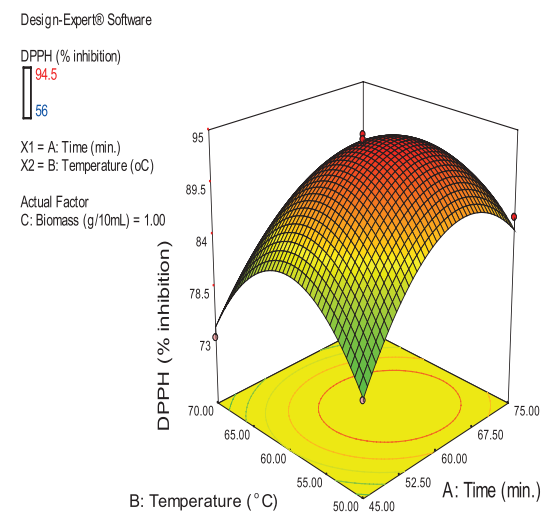

b)

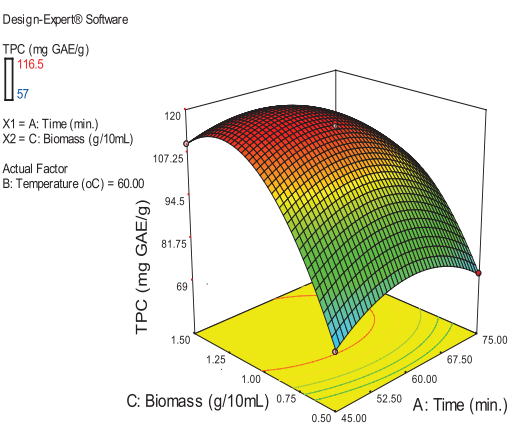

e)

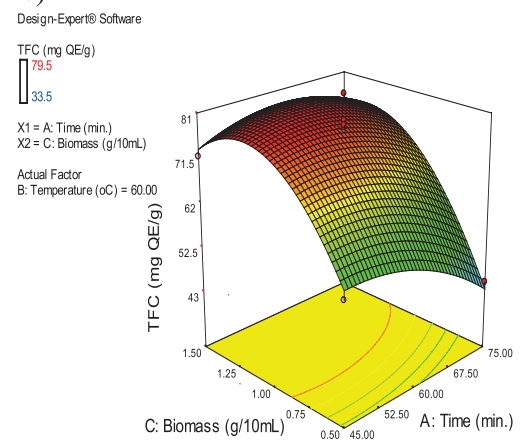

h)

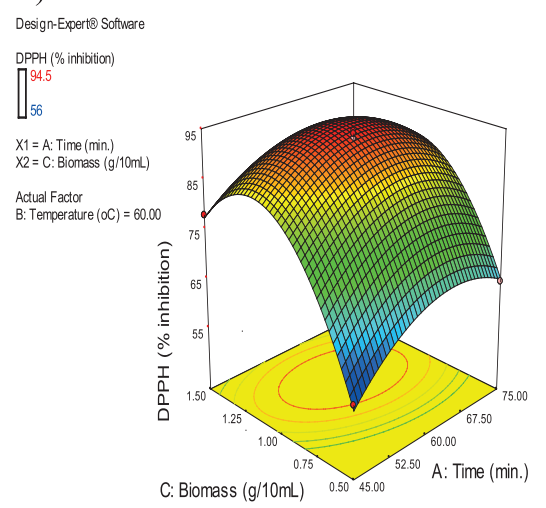

c)

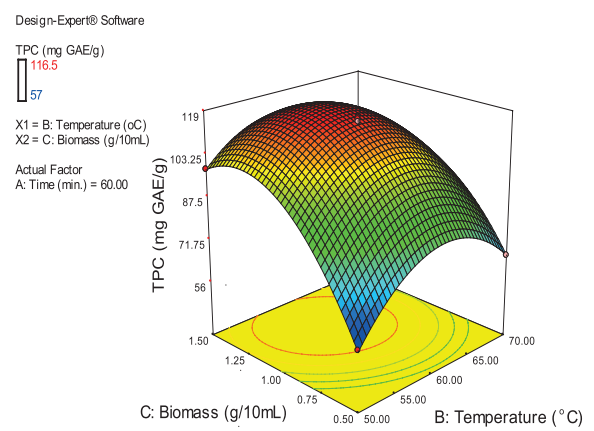

f)

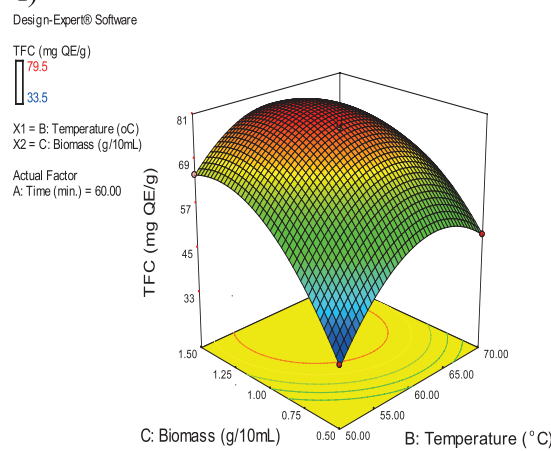

i)

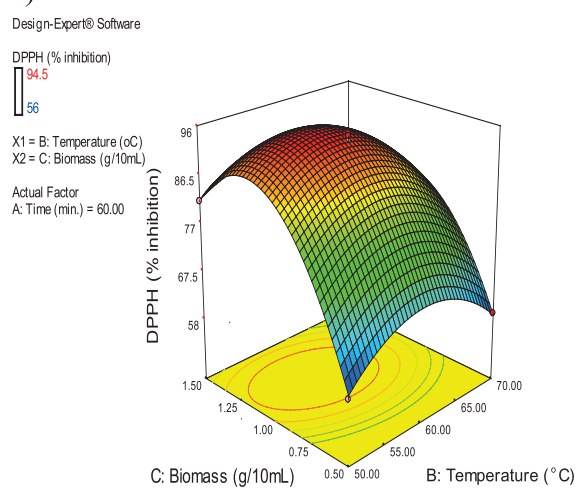

Fig. 2. Effects of process parameters on yields of TPC (a, b, c), TFC (d, e, f), and DPPH (g, h, i). 
Table 4. Antimicrobial activity of M. arvensis extracts against bacterial (S. aureus and E. coli) and fungal strains (F. solani and A. niger).

\begin{tabular}{|c|c|c|c|c|c|c|c|c|}
\hline \multicolumn{5}{|c|}{ Staphylococcus aureus } & \multicolumn{4}{|c|}{ Escherichia coli } \\
\hline & \multicolumn{2}{|c|}{ Inhibition zone (mm) } & \multicolumn{2}{|c|}{$\operatorname{MIC}(\mu \mathrm{g} / \mathrm{mL})$} & \multicolumn{2}{|c|}{ Inhibition zone (mm) } & \multicolumn{2}{|c|}{$\mathrm{MIC}(\mu \mathrm{g} / \mathrm{mL})$} \\
\hline \multirow{2}{*}{ Extracts } & ChCl:Gly & $\mathrm{MeOH}: \mathrm{H}_{2} \mathrm{O}$ & ChCl:Gly & $\mathrm{MeOH}: \mathrm{H}_{2} \mathrm{O}$ & ChCl:Gly & $\mathrm{MeOH}: \mathrm{H}_{2} \mathrm{O}$ & ChCl:Gly & $\mathrm{MeOH}: \mathrm{H}_{2} \mathrm{O}$ \\
\hline & $40.5 \pm 1.4$ & $20.0 \pm 0.4$ & $25 \pm 1.5$ & $25 \pm 2.0$ & $34.5 \pm 1.4$ & $25 \pm 0.8$ & $25 \pm 2.0$ & $50 \pm 2.5$ \\
\hline Rifampicin & \multicolumn{2}{|c|}{$65 \pm 2.4$} & \multicolumn{2}{|c|}{$12.5 \pm 0.9$} & \multicolumn{2}{|c|}{$61 \pm 2.1$} & \multicolumn{2}{|c|}{$12.5 \pm 0.9$} \\
\hline \multicolumn{5}{|c|}{ Fusarium solani } & \multicolumn{4}{|c|}{ Aspergillus niger } \\
\hline & $41.5 \pm 1.4$ & $22 \pm 0.4$ & $12.5 \pm 1.0$ & $50 \pm 2.5$ & $39.5 \pm 1.4$ & $29 \pm 0.8$ & $12.5 \pm 1.5$ & $25 \pm 2.0$ \\
\hline Terbinafine & \multicolumn{2}{|c|}{$55 \pm 4.5$} & \multicolumn{2}{|c|}{$12.5 \pm 0.9$} & \multicolumn{2}{|c|}{$55 \pm 4.5$} & \multicolumn{2}{|c|}{$6.3 \pm 0.9$} \\
\hline
\end{tabular}

time, temperature and biomass-to-solvent ratio did not give the valuable extraction of bioactive ingredients. The medium levels of process variables preferential for effective extraction were explained previously in detail.

\section{Antimicrobial Activities}

The DES extracts showed a larger zone of inhibition $(40.5 \pm 1.4 \mathrm{~mm}$ and $34.5 \pm 1.4 \mathrm{~mm})$ with MIC $(25.0 \pm 1.5 \mu \mathrm{g} / \mathrm{mL}$ and $25 \pm 2.0 \mu \mathrm{g} / \mathrm{mL})$ against $S$. aureus and $E$. coli respectively. The DES extract showed a larger inhibition zone $(41.5 \pm 1.4 \mathrm{~mm}$ and $39.5 \pm 1.4 \mathrm{~mm})$ with MIC $(12.5 \pm 1.0 \mu \mathrm{g} / \mathrm{mL}$ and $12.5 \pm 1.5 \mu \mathrm{g} / \mathrm{mL}$ ) against $F$. solani and $A$. niger respectively. In general, the results verified that all the plant extracts showed the antibacterial and antifungal activity, but less than standard Rifampicin and Terbinafine respectively as shown in Table 4 .

\section{Identifying Bioactive Compounds by Mass Spectrometry}

The phenolics and flavonoids extracted from $M$. arvensis using LC-MS with retention time and $\mathrm{m} / \mathrm{z}$

Table 5. Compounds identified through LC-MS of DES extract.

\begin{tabular}{|c|c|c|c|c|}
\hline Compound & Formula & $\begin{array}{c}\mathrm{Rt} \\
(\mathrm{min} .)\end{array}$ & $\begin{array}{c}\mathrm{m} / \mathrm{z} \\
{[\mathrm{M}+\mathrm{H}]^{+} /} \\
{[\mathrm{M}-\mathrm{H}]^{-}}\end{array}$ & Ref. \\
\hline Chrysin & $\mathrm{C}_{15} \mathrm{H}_{10} \mathrm{O}_{4}$ & 5.5 & 254 & {$[28]$} \\
\hline p-coumaric acid & $\mathrm{C}_{9} \mathrm{H}_{8} \mathrm{O}_{3}$ & 6.1 & 163 & {$[28]$} \\
\hline Naringenin & $\mathrm{C}_{15} \mathrm{H}_{12} \mathrm{O}_{5}$ & 7.2 & 272 & {$[28]$} \\
\hline Scopoletin & $\mathrm{C}_{10} \mathrm{H}_{8} \mathrm{O}_{4}$ & 1.6 & 193 & {$[29]$} \\
\hline Phenylpyruvic acid & $\mathrm{C}_{9} \mathrm{H}_{8} \mathrm{O}_{3}$ & 2.2 & 165 & {$[29]$} \\
\hline Pinocembrin & $\mathrm{C}_{15} \mathrm{H}_{12} \mathrm{O}_{4}$ & 5.8 & 257 & {$[30]$} \\
\hline Hesperidin & $\mathrm{C}_{28} \mathrm{H}_{34} \mathrm{O}_{15}$ & 6.1 & 609 & {$[31]$} \\
\hline Carnosic Acid & $\mathrm{C}_{20} \mathrm{H}_{28} \mathrm{O}_{4}$ & 1.6 & 333 & {$[31]$} \\
\hline Caffeic Acid & $\mathrm{C}_{9} \mathrm{H}_{8} \mathrm{O}_{4}$ & 3.4 & 181 & {$[32]$} \\
\hline
\end{tabular}

are given in Table 5. The bioactive compounds play a significant role in the defensive system against various oxidative and microbial infections with no side effects [25]. Hydroxycinnamic acid derivatives (p-courmaric and caffeic acid) and flavonoids (chrysin, naringenin, phenylpyruvic acid, pinocembrin and hesperidin) have shown a wide range of various pharmacological activities such as antioxidant, antimicrobial and antiinflammation activities, and are thought to exert protective effects against major diseases such as cancer and cardiovascular diseases [26]. Carnosic acid possesses antioxidative and antimicrobial properties [27].

\section{Conclusions}

The DESs are known as green alternative solvents to conventional toxic organic solvents and can be used as environmentally friendly extraction media. These solvents have the ability to dissolve both polar and nonpolar metabolites of flora. Choline chloride and glycerol binary solvent demonstrated better alternatives for the extraction of bioactive compounds from $M$. arvensis as compared to aqueous methanol. This solvent showed better extraction yields of phytochemicals. The RSM has been used as a valuable statistical approach for the optimization of process parameters. It is evident from the results that UAE is useful with higher extraction yields at a shorter time. The DES extracts confirmed effectual antibacterial and antifungal potentials against different biological strains. The choline chloride and glycerol based binary DES can be used as nontoxic solvents for the efficient extraction of phytochemical constituents from medicinal plants.

\section{Acknowledgments}

This study was accomplished with partial financial support of HEC through the Access to Scientific Instrumentation Program (ASIP) under grant No. 202(8)/ASIP/R\&D/HEC/17/00038(HEJ). 


\section{Conflict of Interest}

The authors declare no conflict of interest.

\section{References}

1. ALI M.C., CHEN J., ZHANG H., LI Z., ZHAO L., QIU H. Effective extraction of flavonoids from Lycium barbarum L. fruits by deep eutectic solvents-based ultrasoundassisted extraction. Talanta, 203 16, 2019.

2. ABBOTT A.P., CAPPER G., DAVIES D.L., RASHEED R.K., TAMBYRAJAH V. Novel solvent properties of choline chloride/urea mixtures. Chemical Communications(1), 70, 2003.

3. MACÁRIO I.P.E., OLIVEIRA H., MENEZES A.C., VENTURA S.P.M., PEREIRA J.L., GONÇALVES A.M.M., COUTINHO J.A.P., GONÇALVES F.J.M. Cytotoxicity profiling of deep eutectic solvents to human skin cells. Scientific Reports, 9 (1), 3932, 2019.

4. MENGHANI E., BHATNAGAR K., SARASWAT P., SONI M. Isolation and characterization of bioactives from arid zone plants. International Journal of Pharmaceutical Research and Development, 4 (02), 113, 2012.

5. KRISHNAIAH D., SARBATLY R., NITHYANANDAM R. A review of the antioxidant potential of medicinal plant species. Food and Bioproducts Processing, 89 (3), 217, 2011.

6. SALIN O., TORMAKANGAS L., LEINONEN M., SAARIO E., HAGSTROM M., KETOLA R.A., SAIKKU P., VUORELA H., VUORELA P.M. Corn mint (Mentha arvensis) extract diminishes acute Chlamydia pneumoniae infection in vitro and in vivo. Journal of Agricultural and Food Chemistry, 59 (24), 12836, 2011.

7. RADOŠEVIĆ K., ĆURKO N., SRČEK V.G., BUBALO M.C., TOMAŠEVIĆ M., GANIĆ K.K., REDOVNIKOVIĆ I.R. Natural deep eutectic solvents as beneficial extractants for enhancement of plant extracts bioactivity. LWT-Food Science and Technology, 73, 45, 2016.

8. DRANCA F., OROIAN M. Optimization of ultrasoundassisted extraction of total monomeric anthocyanin (TMA) and total phenolic content (TPC) from eggplant (Solanum melongena L.) peel. Ultrasonics Sonochemistry, 31 637, 2016.

9. ALBERTI A., ZIELINSKI A.A.F., ZARDO D.M., DEMIATE I.M., NOGUEIRA A., MAFRA L.I. Optimisation of the extraction of phenolic compounds from apples using response surface methodology. Food Chemistry, 149 151, 2014.

10. HELENO S.A., DIZ P., PRIETO M., BARROS L., RODRIGUES A., BARREIRO M.F., FERREIRA I.C. Optimization of ultrasound-assisted extraction to obtain mycosterols from Agaricus bisporus L. by response surface methodology and comparison with conventional Soxhlet extraction. Food Chemistry, 197, 1054, 2016.

11. GIUSTI F., CAPRIOLI G., RICCIUTELLI M., VITTORI S., SAGRATINI G. Determination of fourteen polyphenols in pulses by high performance liquid chromatographydiode array detection (HPLC-DAD) and correlation study with antioxidant activity and colour. Food Chemistry, 221, 689, 2017.

12. DO Q.D., ANGKAWIJAYA A.E., TRAN-NGUYEN P.L., HUYNH L.H., SOETAREDJO F.E., ISMADJI S., JU Y.-H. Effect of extraction solvent on total phenol content, total flavonoid content, and antioxidant activity of
Limnophila aromatica. Journal of Food and Drug Analysis, 22 (3), 296, 2014

13. XU Z., FENG S., SHEN S., WANG H., YUAN M., LIU J., HUANG Y., DING C. The antioxidant activities effect of neutral and acidic polysaccharides from Epimedium acuminatum Franch. on Caenorhabditis elegans. Carbohydrate polymers, 144 122, 2016.

14. QURESHI M.N., NUMONOV S., AISA H. Total polyphenolic compounds, total flavonoids, GC-MS analysis of volatile constituents, evaluation of antioxidant and antimicrobial activities of Prunus dulcis nuts. Pakistan Journal of Pharmaceutical Sciences, 32, 1461, 2019.

15. RAMIĆ M., VIDOVIĆ S., ZEKOVIĆ Z., VLADIĆ J., CVEJIN A., PAVLIĆ B. Modeling and optimization of ultrasound-assisted extraction of polyphenolic compounds from Aronia melanocarpa by-products from filter-tea factory. Ultrasonics Sonochemistry, 23, 360, 2015.

16. RAMADOSS G., MUTHUKUMAR K. Ultrasound assisted metal chloride treatment of sugarcane bagasse for bioethanol production. Renewable Energy, 99, 1092, 2016.

17. AL-DHABI N.A., PONMURUGAN K., JEGANATHAN P.M. Development and validation of ultrasound-assisted solid-liquid extraction of phenolic compounds from waste spent coffee grounds. Ultrasonics Sonochemistry, 34, 206, 2017.

18. YIN X., YOU Q., JIANG Z., ZHOU X. Optimization for ultrasonic-microwave synergistic extraction of polysaccharides from Cornus officinalis and characterization of polysaccharides. International Journal of Biological Macromolecules, 83, 226, 2016.

19. MJALLI F.S.AHMAD O. Density of aqueous choline chloride-based ionic liquids analogues. Thermochimica Acta, 647, 8, 2017.

20. JEGANATHAN P.M., VENKATACHALAM S., KARICHAPPAN T., RAMASAMY S. Model development and process optimization for solvent extraction of polyphenols from red grapes using Box-Behnken design. Preparative Biochemistry and Biotechnology, 44 (1), 56, 2014.

21. BI W., TIAN M., ROW K.H. Evaluation of alcohol-based deep eutectic solvent in extraction and determination of flavonoids with response surface methodology optimization. Journal of Chromatography A, 1285, 22, 2013.

22. KATSAMPA P., VALSAMEDOU E., GRIGORAKIS S., MAKRIS D.P. A green ultrasound-assisted extraction process for the recovery of antioxidant polyphenols and pigments from onion solid wastes using Box-Behnken experimental design and kinetics. Industrial Crops and Products, 77, 535, 2015.

23. AIYEGORO O.A., OKOH A.I. Preliminary phytochemical screening and in vitro antioxidant activities of the aqueous extract of Helichrysum longifolium DC. BMC complementary and alternative medicine, 10 (1), 21, 2010.

24. BELWAL T., DHYANI P., BHATT I.D., RAWAL R.S., PANDE V. Optimization extraction conditions for improving phenolic content and antioxidant activity in Berberis asiatica fruits using response surface methodology (RSM). Food Chemistry, 207, 115, 2016.

25. MAKANYANE D.M., EJIDIKE I.P., SSEMAKALU C.C., MTUNZI F.M., PAKADE V.E., KLINK M.J., LEBELO R.S. Gc-MS analysis and extraction optimization of bioactive compoundsfrom Pelargonium graveolens L'hér methanolic extract and their activitiesas pharmacological agents. International Research Journal Of Pharmacy, 10 (9), 59, 2019. 
26. SHAHIDI F., AMBIGAIPALAN P. Phenolics and polyphenolics in foods, beverages and spices: Antioxidant activity and health effects - A review. Journal of functional foods, 18, 820, 2015.

27. BIRTIĆ S., DUSSORT P., PIERRE F.-X., BILY A.C., ROLLER M. Carnosic acid. Phytochemistry, 115, 9, 2015.

28. ERTAŞ A., BOĞA M., YILMAZ M.A., YEŞIL Y., HAŞIMI N., KAYA M.S.E., TEMEL H., KOLAK U. Chemical compositions by using LC-MS/MS and GC-MS and biological activities of Sedum sediforme (Jacq.) Pau. Journal of Agricultural and Food Chemistry, 62 (20), 4601, 2014.

29. FU Z.-F., TU Z.-C., ZHANG L., WANG H., WEN Q.-H., HUANG T. Antioxidant activities and polyphenols of sweet potato (Ipomoea batatas L.) leaves extracted with solvents of various polarities. Food Bioscience, 15, 11, 2016.
30. PULCINI P., ALLEGRINI F., FESTUCCIA N. Fast SPE extraction and LC-ESI-MS-MS analysis of flavonoids and phenolic acids in honey. Apiacta, 41, 21, 2006.

31. WANG M., SHAO Y., LI J., ZHU N., RANGARAJAN M., LAVOIE E.J., HO C.-T. Antioxidative phenolic glycosides from sage (Salvia officinalis). Journal of Natural Products, 62 (3), 454, 1999.

32. ALU'DATT M.H., RABABAH T., ALHAMAD M.N., GAMMOH S., EREIFEJ K., KUBOW S., ALLI I. Characterization and antioxidant activities of phenolic interactions identified in byproducts of soybean and flaxseed protein isolation. Food Hydrocolloids, 61, 119, 2016. 